\title{
DESIGNING YOUR FUTURE BUSINESS MODEL: AN ACTIVITY SYSTEM PERSPECTIVE
}

Christoph Zott

Raphael Amit 


\title{
DESIGNING YOUR FUTURE BUSINESS MODEL: AN ACTIVITY SYSTEM PERSPECTIVE
}

\author{
Christoph Zott ${ }^{1}$ \\ Raphael Amit ${ }^{2}$
}

\begin{abstract}
Building on the received literature, we conceptualize a firm's business model as a system of interdependent activities that transcends the focal firm and spans its boundaries. The activity system enables the firm to create value in concert with its partners but also to appropriate a share of the value created. Anchored on theoretical and empirical research, we suggest two sets of parameters that activity systems designers need to consider: design elements - content, structure and governance - that describe the architecture of an activity system; and design themes - novelty, lock-in, complementarities and efficiency - that describe the sources of the activity system's value creation.
\end{abstract}

Keywords: business model, activity system, design.

Third draft for Long Range Planning Special Issue on Business Models

\footnotetext{
${ }^{1}$ Professor, Entrepreneurship, IESE

${ }^{2}$ Professor, The Wharton School, University of Pennsylvania
} 


\section{DESIGNING YOUR FUTURE BUSINESS MODEL: AN ACTIVITY SYSTEM PERSPECTIVE ${ }^{1}$}

\section{Introduction}

Consider the case of FriCSo, Inc., a young engineering company that has achieved a significant technological breakthrough in friction reduction technology. ${ }^{2}$ Friction is the arch enemy of mechanical systems - it reduces the power of machines, leads to overheating, and causes wear, breakdown and seizure in moving parts. Suppose that the technological invention of FriCSo reduces friction by over $15,000 \%$. Surely such a staggering technology - with clear and wide applicability in industries with products and industrial applications that involve moving parts (such as machine manufacturing, automobile, shipbuilding, etc.) - will be a sure bet for commercial success? Or will it? Once a target industry (say, automobile) has been chosen, what kind of company would you build in order to commercialize the intellectual property? What "model" or "template" of a firm would you adopt in order to embed the new firm into the existing ecology of original equipment manufacturers (OEMs), and the myriad of tier one, two and three suppliers to the industry? Would you choose to become a machine manufacturer, building machines that embed the new technology, and selling them to the OEMs? Or would you rather build and operate a factory (a "job-shop") that would perform the surface treatment of moving parts for clients who would outsource that step in their commercial production line to your factory? Or would you rather opt for a pure R\&D firm that sells its technology (via licensing agreements, for example) to third parties such as machine manufacturers?

Each of these choices involves a fundamentally different business model; that is, each one implies a different set of activities, as well as the resources and capabilities to perform them - either within the firm, or outside it, through cooperation with partners, suppliers or customers. Each of these choices also has implications for the performance potential of the venture: it will affect what capital expenditures are necessary, what prices can be charged, what margins will be

\footnotetext{
${ }^{1}$ Both authors gratefully acknowledge the financial support of the INSEAD-Wharton Alliance Center for Global Research and Development. Raphael Amit acknowledges the generous research support of the Robert B. Goergen Chair and the Wharton e-Business initiative (WeBI). We thank Cesar Guzman-Concha for his research assistance.

${ }^{2}$ C. Loch, C. Zott, A. Guttman, P. Jokela, and D. Nahminas, "FriCSo (A): How to translate a new technology into a business (model)?", INSEAD case study (2008a).
} 
earned, and, perhaps most importantly, the customers and competitors the new firm will deal with. In other words, the design of the business model is a key decision for the entrepreneur who creates a new firm and a crucial task for general managers who are charged with rethinking their old model to make their firm fit for the future. Once the template is set, the activities are in place, and the resources have been developed and honed, that template will be difficult to change, due to forces of inertia and resistance to change.

Given the vital importance of the business model for entrepreneurs and general managers, it is surprising that academic research, with a few exceptions, has so far devoted little attention to this topic. We need a conceptual toolkit that enables entrepreneurial managers to design their future business model, as well as to analyze and improve their current designs to make them fit for the future. In this paper, we draw attention to the system of activities performed by the focal firm as well as by third parties (partners, suppliers, customers) as part of the focal firm's business model. We believe that improved knowledge about how to describe the architecture of the activity system, e.g., its key design parameters, will bring the importance of the topic to the forefront of managers' and researchers' thinking, and help them design better business models. In particular, the concepts we suggest are intended to:

- Give managers and researchers a "language," concrete tools and a tight framework for business model design that can foster dialogue and promote common understanding.

- Highlight design as a key task of the entrepreneurial manager.

- Emphasize the importance of system-level design, as opposed to partial optimization (for example, whether to outsource or conduct in house a particular activity).

We start by describing the firm's activity system and explain how it captures the essence of its business model. We then give a brief review of the recent literature on business models to support this idea. We proceed by drawing on our recent work on business models ${ }^{3}$ to suggest two sets of parameters that activity systems designers need to consider: design elements (content, structure and governance) that describe the architecture of an activity system, and design themes (novelty, lock-in, complementarities and efficiency) that describe the sources of value creation of the activity system.

\section{Activity System: Key to Understanding the Firm's Business Model}

The overall objective of a focal firm's business model is to exploit a business opportunity by creating value for the parties involved, i.e., to fulfill customers' needs and create customer surplus while generating a profit for the focal firm and its partners. ${ }^{4}$ That objective could also be called "the value creating insight on which the firm turns," and it is reflected in the

\footnotetext{
${ }^{3}$ R. Amit and C. Zott, "Value creation in e-business," Strategic Management Journal, 22, 2001, pp. 493-520, C. Zott and R. Amit, Business model design and the performance of entrepreneurial firms, Organization Science, 18, 2007, pp. 181-199, C. Zott and R. Amit, "The fit between product market strategy and business model: Implications for firm performance," Strategic Management Journal, 29, 2008, pp. 1-26.

${ }^{4}$ Amit R. and C. Zott, 2001, op. cit.
} 
customer value proposition. ${ }^{5}$ An activity in a focal firm's business model can be viewed as the engagement of human, physical, and/or capital resources of any part to the business model (the focal firm, end customers, vendors, etc.) to serve a specific purpose toward the fulfillment of the overall objective. An activity system is a set of interdependent organizational activities centered on a focal firm, and encompasses activities that are either conducted by the focal firm or by partners, customers, or vendors. The firm's activity system may transcend the focal firm and span its boundaries, but remain firm-centric to enable the focal firm not only to create value with its partners, but also to appropriate a share of the value created for itself.

Interdependency among activities is central to the concept of an activity system. Interdependencies provide insights into the processes that enable the evolution of a focal firm's activity system over time, as its competitive environment changes. ${ }^{6}$ They are created by entrepreneurs or managers who shape and design organizational activities as well as the links (transactions) that weave activities together into a system. Such purposeful design - within and across firm boundaries - is the essence of the business model. ${ }^{7}$ Some activities relevant to the focal firm's business model will be performed by the firm itself, others by suppliers, partners and/or customers. The architecture of the firm's activity system - shaped by the choice of activities, how they are linked, and who performs them - captures how the focal firm is embedded in its "ecology", i.e., in its multiple networks of suppliers, partners and customers. It also defines who the firm's potential suppliers, partners and customers (and competitors) are in the first place. Consider again FriCSo, the technology-based startup mentioned earlier. If FriCSo were to adopt the business model of a machine manufacturer in order to exploit its unique friction-reduction technology, it would choose OEM suppliers as its customers, and other machine manufacturers as its competitors. However, if it adopted a technology-licensing model, it would choose both machine manufacturers and OEM suppliers as its customers. These important consequences of the firm's business model design choice have obvious ramifications on its ability to create and capture value. The stronger the competition implied by the choice of the business model, for instance, the more difficult value appropriation is.

The firm's revenue model also plays an important role in value appropriation. The revenue model, akin to a pricing strategy for specific products or services, refers to the specific modes in which a business model enables revenue generation. ${ }^{8}$ In that sense, a revenue model complements a business model design, just as a pricing strategy complements a product design. Although the concepts may be quite closely related and sometimes even intertwined - for example, in the product world, Gillette uses its pricing strategy of selling cheap razors to make customers buy its rather expensive blades - business models and revenue models are conceptually distinct.

\footnotetext{
5 J. Magretta, “Why business models matter," Harvard Business Review 80: 5, 2002, pp. 86-92, M. W. Johnson, C. C Christensen and H. Kagermann, "Reinventing your business model," Harvard Business Review 86, 2008, p. 12. ${ }^{6}$ N. Siggelkow, "Change in the presence of fit: The Rise, fall, and the renaissance of Liz Clairborne," Academy of
Management Journal 44, 2001, pp. 838-857.

N. Siggelkow, “Evolution toward fit,” Administration Science Quarterly 47, 2002, pp. 125-159.

${ }^{7}$ C. Zott and R. Amit, "The business model as the engine of network-based strategies," in Paul R. Kleindorfer and Yoram Wind (eds), "Network-based Strategies and Competencies," Wharton School Publishing, Upper Saddle River, NJ (forthcoming 2009).

${ }^{8}$ Amit R. and C. Zott, 2001, op. cit.
} 
A business model is geared toward total value creation for all parties involved. It lays the foundations for the focal firm's value capture by co-defining (along with the firm's products and services) the overall "size of the value pie," or the total value created in transactions, which can be considered an upper limit to the firm's value capture. The business model also co-determines the focal firm's bargaining power. The greater the total value created, and the greater the focal firm's bargaining power, the greater the amount of value that the focal firm can appropriate. ${ }^{9}$ How much of the total value the firm actually captures, however, depends on its pricing strategy, or revenue model. The executives of FriCSo, for example, contemplated a business model based on licensing, in which they would sell the rights to use their technology (a combination of software-supported processes and proprietary polymer tools) to machine manufacturers and suppliers in the automobile industry. But even though they understood how the necessary activity system would have to be designed, they struggled to find an appropriate revenue model (embodied in their pricing strategy) that would be acceptable to their automotive clients, and that would allow them to maximize their profits. While their business model had taken shape, the venture's revenue model - how to charge for each element of the technology - was still uncertain. ${ }^{10}$

When delineating their firms' activity systems, managers need to bear in mind that identifying technologically and/or strategically distinct activities can be conceptually challenging because the number of potential activities is often quite large. ${ }^{11}$ Many seemingly inseparable activities can be broken down further, especially given ongoing advances in information and communications technologies. ${ }^{12}$ One way to deal with this issue is to define activities at different levels of aggregation. Davenport, ${ }^{13}$ for example, mentions the supply chain operations reference model, which lays out top-level activities (plan, source, make, deliver, and return), and also specifies sub-activities that can be delineated at second, third, and fourth levels. At high levels of aggregation, activities could comprise whole business functions, such as accounting, or human resource management. ${ }^{14}$ At low levels of aggregation (i.e., high levels of decomposition), activities could be as specific as the processing of customer e-mails based on their content, or the translation of product manuals into a foreign language. For conceptual

\footnotetext{
${ }^{9}$ Zott, C. and R. Amit, 2007, op. cit.

${ }^{10}$ Loch, C. et al., 2008a, op. cit.; C. Loch, C. Zott, A. Guttman, P. Jokela, and D. Nahminas, "FriCSo (B): Designing the new business model," INSEAD case study (2008b).
}

${ }^{11}$ M. E. Porter, “Competitive Advantage: Creating and Sustaining Superior Performance,” The Free Press, New York, 1985.

12 F. M. Santos, "Toward an entrepreneurial theory of boundaries: The scalability of firms in nascent markets," Working paper, INSEAD, Fontainebleau, 2006.

${ }^{13}$ T. Davenport, “The coming commoditization of processes," Harvard Business Review, 83, 6, 2005, pp. 100-108.

${ }^{14}$ The economics-oriented approach to conceptualizing organizational activities focuses on high-level activities such as the firm's production function. Stigler, for example, views "the firm as engaging in a series of distinct operations: purchasing and storing materials; transforming materials into semifinished products and semifinished products into finished products; storing and selling the output; extending credit to buyers; etc." In a similar vein, Porter defines activities as the building blocks by which a firm creates a product. He contends that potentially valuable differentiation arises from the choice of activities and how they are performed, and cost is generated by performing activities, so activities are the basic units of competitive advantage. G. J. Stigler, "The division of labor is limited by the extent of the market," Journal of Political Economy, 59, 1951, pp. 185-193, Porter, M. E., op. cit.; M. E. Porter, "What is strategy?," Harvard Business Review, 74, 1996, pp. 61-79. 
clarity and simplicity in this paper, we accept the level of aggregation at which an activity is described as a given.

\section{Brief Review of the Recent Literature on Business Models}

The emerging literature on business models suggests that a focus on activities can indeed be useful and unifying. In our own work, we have defined the business model as depicting "the content, structure, and governance of transactions designed so as to create value through the exploitation of business opportunities." ${ }^{15}$ of course, transactions link activities, ${ }^{16}$ and transactions and activities can be viewed as two sides of the same coin. For an analogy, consider graph theory with its dual perspectives on nodes and arcs. One can describe a graph either by focusing on its nodes and by listing all the other nodes to which they are linked, or by focusing on the arcs and describing which nodes pertain to each arc. Both foci are equivalent in that they yield a complete description of the graph. Therefore, a business model can either be conceptualized as set of transactions or as an activity system - a "system that is made up of components, linkages between the components, and dynamics." ${ }^{17}$

Viewed as an activity system, the business model encompasses "the set of which activities a firm performs, how it performs them, and when it performs them." Key activities might include "training, development, manufacturing, budgeting, planning, sales, and service." The business model thus addresses the "how" of providing customers and end-users with products and services. Indeed, it refers to the nature of the services that firms provide to customers, and the activities that they perform to deliver those services. Put differently, the business model mediates between technological inputs and economic outputs. Accordingly, the business model defines the structure of the value chain, i.e., "the set of activities from raw materials through to the final consumer... with value being added throughout the various activities." It thereby addresses the underlying logic of how the firm delivers value to its customers at an appropriate cost. In a nutshell, the received literature on business models, explicitly or implicitly, supports an activity system perspective ${ }^{18}$.

Some scholars have explicitly pointed to the boundary-spanning nature of business models by emphasizing the need to consider activities performed for the focal firm but outside its boundaries by partners, suppliers or customers. This allows the focal firm to rely on the

\footnotetext{
${ }^{15}$ Amit R. and C. Zott, 2001, op. cit.

16 0. E. Williamson, "Organizational innovation: The transaction cost approach," in J. Ronen (ed.), “Entrepreneurship," Lexington, MA: Lexington Books, 1983, pp. 101-134,
}

17 A. Afuah and C. L. Tucci, "Internet Business Models and Strategies: Text and Cases," Irwin/McGraw-Hill: New York, NY, p. 4, 2000.

${ }^{18}$ A. Afuah, “Business Models: A Strategic Management Approach,” McGraw-Hill/Irwin: New York, NY 2004, p. 9; Johnson, M. W., et al. op. cit., p. 53; D. Mitchell and C. Coles, "The ultimate competitive advantage of continuing business model innovation," Journal of Business Strategy, 24, 2003, pp. 15-21; T. R. Eisenmann, "Internet Business Models," McGraw-Hill Irwin: New York: NY, 2002, p. 12; H. Chesbrough and R. S. Rosenbloom, "The role of the business model in capturing value from innovation: Evidence from Xerox Corporation's technology spinoff companies," Industrial and Corporate Change, 11, 2002, pp. 533-534; Porter, M. E. 1985, op. cit., H. Chesbrough, “Open Business Models," Harvard Business School Press: Boston: MA, 2006, p. 2; Magretta, J., op. cit. 
resources and capabilities of third parties, and harness external ideas and technologies through "open business models." Indeed, in some instances entire key activities such as product development are shifted outside the firm, but they remain a central part of the firm's business model. $^{19}$

\section{The Design Parameters of Activity Systems}

In this section, we describe two sets of design parameters of activity systems that capture the purposeful, firm-centric design of the activity system.

\section{a. Content, structure, and governance as design elements}

One set of important design parameters that characterize an activity system is content, structure, and governance, which go beyond interdependencies among activities or notions of network structure. ${ }^{20}$

- The content of an activity system refers to the selection of activities, i.e., those that are performed. For example, in addition to the typical activities of a retail bank, Bancolombia adopted activities to offer microcredit to reach the more than $60 \%$ of Colombians who did not have access to banking services. To perform these new activities, the bank needed to train its top management, hire and train new staff, develop new capabilities, and link the new activity to its existing system (platforms, applications, and channels). ${ }^{21}$

- The structure of an activity system describes how the activities are linked (e.g., the sequencing among activities), and it also captures their importance for the business model, for example, in terms of their core, supporting, or peripheral nature. ${ }^{22}$ Consider IBM. $^{23}$ Triggered by a severe financial crisis in the early 1990s, the firm switched its core and peripheral activities, shifting its focus from a supplier of hardware (old core) to becoming a service provider (new core). Building on a body of knowhow built over decades, IBM launched a range of new activities in consulting, IT maintenance, and other services. As a result, more than half of IBM's \$90b revenues in 2006 came from these activities, which had barely existed 15 years earlier.

\footnotetext{
${ }^{19}$ Amit, R. and C. Zott, 2001, 2007, 2008, 2009, op. cit.; Chesbrough, H., 2006, op. cit., G. K. Lee and R. E. Cole, "From a firm - based to a community - based model of knowledge creation: The case of the Linux kernel development," Organization Science, 14, 2003, pp. 633-649; E. Von Hippel and R. Katz, "Shifting innovation to users via toolkits," Management Science, 48, 2002, pp. 821-833.

${ }^{20}$ Amit, R. and C. Zott, 2001, op. cit.

${ }^{21}$ S. Banerjea, R. Kahn, C. Petit, “Dare To Be Different. Why Baking Innovation Matters Now," Somers, NY: IBM Global Services, 2006.

${ }^{22}$ Siggelkow, N., 2002, op. cit.

${ }^{23}$ See, for example, H. Chesbrough, "Business model innovation: it's not just about technology anymore," Strategy and Leadership, 35, 2007, pp. 12-17.
} 
- The governance of an activity system refers to who performs the activities. Franchising, for example, represents one possible approach to activity system governance. It can be the key to unlocking value, as was the case for Japanese retailing when entrepreneur Toshifumi Suzuki realized in the early 1970s that the franchise system developed in the United States was an ideal response to the strict regulations imposed by the Japanese government on retailing outlets (e.g., limiting their size, and restricting opening times). By franchising Seven-Eleven stores in Japan, Suzuki adopted a novel type of activity system governance and managed to create value through professional management and local adaptation. ${ }^{24}$

Managers often need to make decisions on all these parameters, often simultaneously. For example, consider P2P lending companies like Lending Club, Prosper, or Zopa, which aim at enabling direct small, unsecured loans between individuals. Important business model design issues for the founders in the early stages of these firms were: 1) whether to include a secondary market for trading loans in their activity systems or not (a content issue); 2) how precisely to link borrowing and lending activities - for example, would they provide an algorithm that automatically matches borrowers to lenders, and if so, to whom and to how many? (a structure issue), and 3) who should perform the credit risk assessment of the borrower, the P2P firm or the lender (a governance issue)?

For simplicity and conceptual clarity, we have described the design parameters of activity systems as independent and orthogonal, but they could also be highly interdependent. Take the United States P2P lending company Prosper, for example. The founders of Prosper made the conscious early decision to let lenders choose the borrowers to whom they wanted to lend their money. This was a structural choice (settling the question of how lending and borrowing activities were linked) but at the same time constituted a decision about governance (the evaluation and selection activities were shifted to the customers, and not performed by the firm).

Thus, activity system design describes how firms do business, and captures the essence of the business model. Questions about business model design can thus be framed as questions about activity systems.

\section{b. NICE design themes: Novelty, lock-In, Complementarities, Efficiency}

An activity system can also be characterized through what we call "design themes," the system's dominant value creation drivers. Design themes are configurations of design elements, or the degree to which design elements are orchestrated and connected by distinct themes. Conceptual and empirical research has established that the common design themes that orchestrate and connect the elements of an activity system inlcude Novelty, lock-In, Complementarities and Efficiency (summarized by the acronym NICE) ${ }^{25}$

\footnotetext{
${ }^{24}$ K. Nagayama and P. Weill, “7-Eleven Japan Co. Ltd.: Reinventing The Retail Business Model," Cambridge MA: Sloan School of Management, 2004.

${ }^{25}$ Amit, R. and C. Zott, 2001, op. cit.
} 
The essence of novelty-centered activity system design is the adoption of new activities (content), and/or new ways of linking the activities (structure), and/or new ways of governing the activities (governance). A prominent example is Apple, which used to be focused on the production of innovative hardware such as personal computers. Through the development of the iPod and the associated music download business iTunes, Apple was the first electronics company to include music distribution as an activity (content novelty), linking it to the development of the iPod hardware and software (structure novelty), and digitizing it and thereby pushing many subactivities of legal music downloads to its customers (governance novelty). That is, Apple expanded the locus of its innovation from the product to its business model.

Lock-in

Activity systems can also be designed for lock-in; their power to keep third parties attracted as business model participants. Lock-in can be manifested as switching costs, or as network externalities that derive from the structure, content and/or governance of the activity system. For example, in eBay's activity system, most of the marketing and sales activities (such as photographing and describing items for sale) are performed by the customers (sellers). What keeps them attracted to eBay and motivates them to perform these activities? What prevents them from switching to other service providers? Arguably, one very important factor is the strong positive network externalities inherent to the eBay activity system. With a massive base of potential buyers, sellers know that they are more likely to perform a trade at a convenient price on eBay than elsewhere. That's why they keep coming back - they are locked in. The same applies to social networking sites such as Facebook. Besides enjoying friendship-based networking externalities, Facebook members typically invest considerable time and effort in personalizing their web pages. These investments form strong impediments to switching to other providers.

\section{Complementarities}

Complementarities are present whenever bundling activities within a system provides more value than running activities separately. For example, in commercial banking, a deposit activity is an important source of funding that complements the banks' lending activity. Banks without access to these funds suffered severely in the recent liquidity crisis. Consider the pharmaceutical industry, where R\&D conducted by innovative biotechnology firms provides the drug pipeline for the marketing and distribution activities of large pharmaceutical firms. Similarly, in the diamond business, organizing, polishing and distribution under one roof is advantageous because it enables the firm to tailor stones to the demand in each market segment.

\section{Efficiency}

Efficiency-centered design refers to the ways in which firms aim at achieving greater efficiency through the design of their activity systems. An efficiency-centered activity system aims at reducing transaction costs. For example, a focal firm may decide to integrate vertically into activities to avoid being taken hostage by its trading partners, who may have an incentive to exploit a situation of co-dependency. Or consider the reverse case, in which a firm manages to standardize the interfaces between activities in its system, and so lower its transaction costs by outsourcing some activities to third parties. This is behind the rise of the business process outsourcing industry in India, where companies like TCS, Wipro, Infosys, Satyam or WNS have more than 20,000 employees each and revenues over \$1b. Another example is First Data 
Corporation, a United States firm that handles crucial activities for credit card companies, such as dealing with applications, authorizing credit lines, or processing transactions. First Data employs about 30,000 people, and handles about 420 million credit card accounts for about 1,400 card issuers. ${ }^{26}$ These are examples of efficiency-centered designs where the governance of the activity system is implied. Firms can also aim at achieving efficiency through their activity system content and structure. Some low cost airlines entirely drop activities considered standard by regular airlines, like on-board catering or seat assignment, and change the way activities are performed and linked to each other (e.g., when customers book tickets directly online).

\section{Benefits of an Activity System Perspective on Business Models: Discussion and Conclusion}

In this article, we argue that the activity system perspective on business models is consistent with the various approaches that have been advanced in the literature. A business model can be viewed as a template of how a firm conducts business, how it delivers value to stakeholders (e.g., the focal firms, customers, partners, etc.), and how it links factor and product markets. The activity system perspective addresses all these vital issues, and gives managers and academics a language and a conceptual toolbox to address them and to engage in insightful dialogue and creative design.

Let's return to FriCSo, the company that developed a world-class technology for friction reduction, and then had to decide on its future business model. The founders and the venture capital investors jointly decided to reject the choice of a machine manufacturing business model. It would have been too capital-intensive and would have pitted the small start-up against powerful and entrenched competitors with similar activity systems and resource advantages that it would have found hard to beat. ${ }^{27}$ Instead, FriCSo adopted the business model of a manufacturer of machine tools, positioning itself as a supplier to the powerful players, and focusing on selling them products that had great value added through their intellectual property. (Another advantage was that suppliers to the automotive industry were used to buying tools, so this business model was familiar to them.) In this case the choice of the business model was vitally important: it did not simply determine future profit potential; it was a question of life or death for the young firm. If the founders had elected to adopt a machine manufacturing model, they would probably not have received the equity capital they needed from their VC investors. Without the funds to finance its ongoing research and development efforts, the firm may have gone out of business.

Why is the activity system perspective advantageous for managers and academics concerned with past, current, and future business models? First, a focus on activities is a natural perspective for entrepreneurs and managers who must decide on business model design. Should activities $\mathrm{X}$ and Y, which are central to the business model, be governed within or without their focal firm's boundaries? How should X and Y be organized, given the firm's and its potential partners' pre-

\footnotetext{
${ }^{26}$ BusinessWeek, “The future of outsourcing (special report)," January 30, 2006, pp. 50-64.

${ }^{27}$ Loch, C. et al., 2008b, op. cit.
} 
existing strengths and weaknesses, core competencies and disabilities? ${ }^{28}$ The importance of activities-based thinking is also evident from the extensive managerial literature on outsourcing. ${ }^{29}$

Second, the activity system perspective encourages systemic and holistic thinking when designing the business model of the future, instead of concentrating on isolated, individual choices (such as the "make or buy" decision about a particular product, or the outsourcing of a particular activity). The message to managers is clear: look at the forest, not the trees - and get the overall design right, rather than optimizing details. Fashion retailer Inditex, a fast-growing Spanish firm that manages global brands such as Zara, has clearly understood and internalized this message and made business model thinking a corporate priority. Their Annual Report begins by explaining the Inditex business model and highlights its innovative elements. ${ }^{30}$ The company has made many activity system choices that, viewed in isolation, seem inefficient. For example, they perform many generic activities in-house, such as the dyeing and cutting of fabric, and the washing, ironing, and ticketing of finished garments. Moreover, they outsource sewing to small workshops located close to their Spanish production facilities. Both of these choices are questionable. As a whole, however, their carefully designed activity system allows Inditex to bring new fashionable garments from the design stage to the shop floor within record time - days as opposed to months - which makes a big difference in the fast-moving fashion business.

Third, a focus on activities allows us to relax several assumptions made in the transaction cost economics (TCE) literature - for example, that the governance issues of firms involved in an exchange are homogeneous. Focusing on activities allows us to shift the focus to a focal firm that must make a decision about its business model design, e.g., how to link a new activity to its current business model, and who should govern that activity. Indeed, of the two parties involved in a bilateral exchange, in practice only one has to make a decision about its business model, e.g., whether to outsource an activity or not. This is the focal firm. Its counterpart may be a specialized provider of services for whom this question is irrelevant. Moreover, much of the TCE literature assumes homogeneity in firms' production capabilities and costs - assets are assumed to be equally productive in the hands of different firms, given the same governance arrangements and transaction characteristics. ${ }^{31}$ Indeed, in the TCE analysis of governance structures, production costs are largely determined by transaction attributes rather than by the attributes of the firms involved in the exchange. ${ }^{32}$ By contrast, much of the recent strategy literature acknowledges firms' differential resource endowments and heterogeneity in the way these are deployed in

28 0. E. Williamson, "Strategy research: Governance and competence perspectives," Strategic Management Journal, 20, 1999, p. 1103.

${ }^{29}$ See, for example, S. Burdon, and A. Bhalla, "Lessons from the untold success story: Outsourcing engineering and facilities management," European Management Journal, 23, 2005, pp. 576-582; J. B. Quinn and F. G. Hilmer, “Strategic outsourcing," Sloan Management Review, Summer, 1994, pp. 43-55.

30 “Inditex Annual Report 2007,” 2008.

31 K. R. Conner and C. K. Prahalad, A resource-based theory of the firm: Knowledge versus opportunism, Organization Science 7, 1996, pp. 477-501.

32 M. H. Riordan and 0. E. Williamson, “Asset specificity and economic organization," International Journal of Industrial Organization 3, 1985, pp. 365-378. 
activities. $^{33}$ An activity systems perspective on business models encourages the incorporation of those ideas and promotes a synthesis of theoretical perspectives.

A fourth advantage of our proposed conceptualization is that it embodies rich possibilities for further theoretical development and refinement. For example, we might consider more carefully how activities are produced by organizational actors drawing on various resources - that is, we might consider the social aspects of relationships among business model participants, in addition to the transactional dimension of these relationships. In a landmark contribution, Weick and Roberts explain how the interrelated actions of organizational actors, when performed "heedfully," minimize the risk of serious accidents during the starting and landing of planes on aircraft carriers. ${ }^{34}$ These developments are valuable because they point to the importance of social action and interaction as the micro-foundations of business model performance. To explore the relationship between individual actions, organizational activities, and business model performance further, scholars could also draw on activity theory, which to date has received scant attention in the management and organization literatures. ${ }^{35}$ The activity system perspective on business models encourages researchers and managers to consider what goes on within the "black box" of activities, and suggests possibilities for probing deeper and gaining a better understanding of the micro-mechanisms of business models, for example by drawing on social theories of action.

To summarize, the main contribution this paper is to develop an activity system perspective on the business model. The activity system perspective could be an important step toward fostering improved empirical understanding of past and current business models, the development of cumulative predictive theory on business model design, and the development of new and exciting future business models.

${ }^{33}$ See, for example, R. Amit, and P. Schoemaker, "Strategic assets and organizational rent," Strategic Management Journal, 14, 1993, pp. 33-46; M. Peteraf, "The cornerstone of competitive advantage: A resource-based view," Strategic Management Journal, 14, 1993, pp. 179-191.

${ }^{34}$ K. E. Weick and K. H. Roberts, "Collective mind in organizations: Heedful interrelating on flight decks," Administrative Science Quarterly, 38, 1993, pp. 357-381.

${ }^{35}$ For exceptions, see F. Blackler, "Knowledge and the theory of organizations: Organizations as activity systems and the reframing of management," Journal of Management Studies, 30, 1993, pp. 863-884; P. Jarzabkowski, "Strategy As Practice: An Activity-Based Approach," London: Sage, 2005; J. C. Spender, "Organizations are activity systems, not merely systems of thought," Advances in Strategic Management, 12B, 1995, pp. 154-174. Activity theory was originally developed by Russian psychologists with the objective of explaining the links between individual thought, behavior, and action, and collective practices in society (e.g., L. Vygotzki, "Mind in Society," Cambridge, MA, Harvard University Press, 1978. It offers a theoretical anchoring of the activity concept that could also be useful for the study of business models. According to the theory, an activity fulfils a specific need or objective, and involves human action and interaction. All actions and interactions that contribute toward the fulfillment of the specific need or objective are part of the activity. Organizational activity can thus be conceived as collective, goal-oriented action, a social process that is shaped by its context and that in turn shapes the context. These concepts could help us better analyze and understand the origin and evolution of business models, and the dynamics of business model change. 